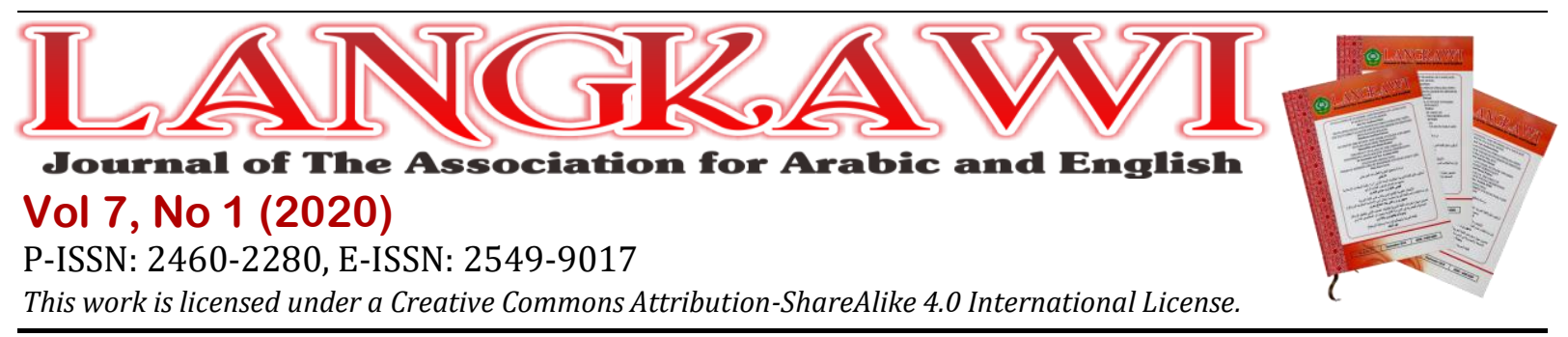

\title{
The Emotional Geography of A Female EFL Pre-service Teacher in Teaching Practicum: Voice from Initial Teacher Education
}

\author{
Misdi $^{1}$, Desy Rachmawaty ${ }^{2}$, Nurani Hartini ${ }^{3}$, Kardi Nurhadi ${ }^{4}$ Hendriwanto ${ }^{5}$ \\ ${ }^{1}$ Universitas Swadaya Gunung Jati, Cirebon, Indonesia. E-mail: misdirina@gmail.com \\ ${ }^{2}$ Universitas Swadaya Gunung Jati, Cirebon, Indonesia. E-mail: desyrachma17@gmail.com \\ ${ }^{3}$ Universitas Swadaya Gunung Jati, Cirebon, Indonesia. E-mail:nuranihartini@gmail.com \\ ${ }^{4}$ Universitas Wiralodra, Indramayu, Indonesia, E-mail: kardi.nurhadi84@unwir.ac.id \\ 5Universitas Swadaya Gunung Jati, Cirebon, Indonesia. E-mail: hendri46@gmail.com
}

\section{ARTICLE INFO \\ Keywords: \\ Emotional geography; EFL Pre-service teacher; Narrative; Teaching practicum}

How to cite:

Misdi, M., Rachmawaty, D., Hartini, N., Nurhadi, K., Hendriwanto, H. (2021). The Emotional Geography of A Female EFL Pre-service Teacher in Teaching Practicum: Voice from Initial Teacher Education. Langkawi Journal of The Association for Arabic and English, 7(1), 106-118.

DOI:

http://dx.doi.org/

10.31332/lkw.v7i1.2321

History:

Received: 2020-11-24

Accepted: 2021-06-08

Published: 2021-06-22

\begin{abstract}
Despite a surge of research interest in pre-service teachers' experiences in teaching practicum over the past years, scant attention has been paid to exploring pre-service teachers' emotional aspects in teaching practicum. This study seeks to fill this gap by investigating the emotional experiences, in particular the emotional geography of a female pre-service teacher who has just completed her teaching practicum situated in Indonesian teacher education, by adopting a narrative inquiry. The data were derived from interviews capturing the critical incidents of her emotional geography while interacting with her cooperating teacher, students and teacher educator. The data were qualitatively analyzed with Hargreaves' emotional geography framework, including physical, moral, socio-cultural, professional and political geography. Drawing on the findings, the participant expressed a wide range of positive and negative emotions such as dealing with a scary-imaged person, being more attentive employing bilingualism during then instruction, getting customized with varieties of instructional media, and being good feeling. This study implied that the policymakers, teacher educator, and cooperating teacher should pay preservice teacher teaching skills and the emotional aspect to get emotional understanding for continuing learning to teach in teacher education landscape.
\end{abstract}

\section{Introduction}

Professional experience or teaching practicum can mediate genuine learning in the teacher education program to teach from theory to practice. It aims to provide authentic experiences for pre-service teachers to grow their teaching skills and develop pedagogical skills and the teaching profession in teacher education landscape (Kaldi \& Xafakos, 2017). This is important as key factor of high teacher performances are frequently associated with her/his strong pedagogical quality (Hargreaves \& Shirley, 2012) which much develops during teaching practicum.

During the past decades, research on teacher emotions has paid great attention to many scholars from different perspectives (Bullock, 2013; Hargreaves, 2001; Zembylas, 2003, 2005). For example, as Zembylas and Schutz argued (2009), reported teacher emotions as intimately connected to teachers' well-being, identity, 
and emotion regulation in teaching, as well as 'a key dimension in teachers' lives, especially in times of change - demographic changes, social and cultural changes, large-scale educational reforms - in which emotions are further intensified' (p. 370). As documented in the literature, emotion "function as the 'the glue' for shaping teachers' identity" (Haviland-Jones \& Kahlbaugh, 2004, p. 294).

Another relevant study by Zhu (2017) found that a wide range of emotions have been expressed by Chinese student teachers, including eagerness and anxiety at the beginning of the teaching practicum and shock and embarrassment were voiced at the end of teaching practicum. Drawing on the research findings, the researcher has addressed that student teachers were trapped in four ethical dilemmas in a teaching practicum, including: (1) tensions between classroom authority and the ethic of caring; (2) acting as a community member or an 'outsider'; (3) working as an office assistant or a 'real teacher'; (4) conflicting pedagogies regarding teaching different tracks of students. This study implied that the teacher educators' should pay attention to student teachers emotional aspect and ethical dilemmas in teaching practicum as the emotion and ethical dilemmas play a pivotal role in constructing professional identity of teacher. In recent years, a growing body of teaching practicum as platform of teacher professional development has been the cornerstone of great concern. In teaching practicum programs, the emotion of pre-service play important aspect where pre-service teachers re-construct their agency culturally and socially. In this sense, the teaching practice is one of the obligated courses that preservice teachers must fulfill to have a proper chance to do what they have learned along their course work in real school classrooms (Darling-Hammond, 2009; Sulistiyo, Mukminin, Abdurrahman, \& Haryanto, 2017).

To date, pre-service teachers have such great tensions along with teaching practice. Teaching practicum is a useful platform for providing student teachers with experience in learning to teach in teacher education and preparation program. Many of the pre-service teachers during their teaching practice confront many challenges and emotions in dealing with a kind of conditions entailing not only those related to students but also to the socio-cultural contexts in a particular school where they accomplish their teaching practice (Riesky, 2013).

The previous study has revealed the important issues of emotional views of pre-service teachers. This study, e.g. Dotger, Harris, Maher \& Hansel (2011), reported how pre-service teachers' emotions simulated parent-teacher and pre-service teacher conference. The findings indicated three different frameworks of emotional geography were professional, moral, and political geographies. Those emotional geographies showed in various emotions of pre-service teachers that most nervous in communicating with parents who had various characteristics and conditions such as supportive, worried, frustrated, and angry about their children or school during.

Rejeki, Kristina, and Drajati (2018) reported the portrait of a female English teacher who had taught in one of the rural areas in Indonesia. The findings discovered one framework of socio-culture of emotional geography. It showed some participants' emotions, which were created by different cultures and social backgrounds between the participant and the rural area where she was placed. However, she was able to handle that situation, although there was a little 
uncomfortable feeling. The point was, those differences did not disrupt her work or task especially related to her communication with the societies.

In terms of emotional geography aspect, Liu (2016), in his study, revealed how an immigrant teacher's experience in the professional community and how she overcame emotional challenged toward the community understandings. The findings indicated different frameworks of emotional geography of physical, moral, socio-cultural, professional, and political geographies were mattered to shape their positive and negative emotions.

Despite of a myriad study on exploring how pre-service teachers emotional experience in teaching practicum, little is paid on investigating pre-service teachers emotional geography while they were interacted with students, mentor teacher and faculty member situated in initial teacher education. Against this backdrop, this research focuses on capturing pre-service teachers' emotional experiences, in particular emotional geographies, in teaching practicum. Thus, this research aims at exploring the emotional geography of an English pre-service teacher, especially about the female EFL pre-service teacher' emotions during her teaching practice experience. Addressing the pre-service teachers' emotions will contribute to the emotional bond among the teacher educators, cooperating teacher and pre-service teachers in which they could grow emotional connections for a fruitful teaching practicum and professional learning situated in initial teacher education. The research question guides this study is presented. "What emotional geographies are revealed in the narratives of the female EFL pre-service teacher's experience in teaching practice?"

\section{Method}

\subsection{Research Context}

This research explored the pre-service teacher's emotional geography (Hargreaves, 2001) on the teaching practice in school. The teaching practice has many things related to relationships, activities, and situations among the pre-service teacher with the students, with the teachers, the people in school, and the pre-service teachers with their own selves towards the complexity of its process. Those are about "human interactions and relationships" (Hargreaves, 2001) that can create emotions the participant experienced about herself and the school environment in teaching practice.

This was a qualitative research as it focuses on investigating the quality of relationships, activities, situations, or materials (Fraenkel, Wallen, \& Hyun, 2012). Qualitative research also pays attention to how people make sense out of their lives. According to Fraenkel, Wallen, \& Hyun (2012), the researcher is the key instrument in this kind of study. They add that the researcher does their best to arrest the participants' thoughts from their perspective as accurately as possible (p. 427).

\subsection{Research Design}

In conducting this research, the writers used a narrative inquiry approach. In recent years, narrative inquiry has been increasingly used to understand human experience (Liu, 2016). It focuses on the meaning and experience "revealed in stories" (Connelly \& Clandinin, 1999; Liu, 2016). In line with them, Heigham \& Croker (2009, p. 46) states that the point of narrative inquiry is "a story or collection of stories." It is 
held to collect or gain the narrative. Through narrative, people can "understand or make sense" (Bruner, 2003; Heigham \& Croker, 2009) about life and experience. So, narrative inquiry is the study of experience as a story, which drawing on Bruner's (2004) stated that it is a major and significant way of thinking about experience (Connelly \& Clandinin, 1999; Liu, 2016). It also can deliver "the changing conditions of lives and the impact these new conditions can have overtime on all aspects of an individual's life" (Heigham \& Croker, 2009, p. 47). Therefore, it seemed to be an appropriate approach for investigating how pre-service teacher went through her teaching practice process which involves changes over herself before, whilst, and after having teaching practice in school. Talking about a story or narrative in research, "a story can be researched when it is interpreted in view of the literature of a field, and this process yields implications for practice, future research or theory building" (Heigham \& Croker, 2009, p. 46). Narrative inquiry has been used in the education field of English language teaching to explore emotional geography (Liu, 2016) for a review of the literature on narrative inquiry in language teaching and learning (Heigham \& Croker, 2009, p. 47).

\subsection{Research Participant}

The participant of this research was a female pre-service teacher (Prili, pseudonym, 21 years old) studying at English Education Department of the Faculty of Teaching and Educational Sciences in a private university in Cirebon, Indonesia. They had accomplished teaching practice in school. Previously, the writers observed 3 classes of the eighth semester's students at English Education Department as "the group of interest to the researcher" (Fraenkel, Wallen \& Hyun, 2012, p. 106). From those 3 classes, there were only 10 students who gave accessed. From 10 students, there were 3 of them who suitably met the criteria of having rich new insights of emotional geography. Then, from those 3 students, there was only 1 student who was easily, willingly, and voluntarily be recruited and interviewed. The process took 4 months (April-July 2020), where the first author served as the mentor of teaching practicum from observing the population to finally interviewing the participant. In the third month, the writers contacted the 10 pre-service teachers, pursued them to 3 , and then finally came to 1 participant. At the last of the third month and the beginning of the fourth month, the writers interviewed the participant. Following ethical protocols, the interview was held after having a negotiation between the writers as interviewers and the participant as respondent about the time and the media of the interview to create comfort for the respondent.

\subsection{Data Collection}

The writers collected the data through interviews. In qualitative research, interview is defined as a purpose-intended conversation (Heigham and Croker, 2009) or "professional conversation" (Heigham \& Croker, 2009, p. 183; Kvale, 1996). It hands over a way to explore people's experiences and can provide important insights into people's experiences, beliefs, perceptions, and motivations" (Heigham \& Croker, 2009, p. 18).

The interview was carried out in an open-structured interview. The entire plan of how to interview the respondent was designed, but the interview itself went in an open way where "questions are not pre-determined" (Heigham \& Croker, 2009, 
p. 185) or does not "involve any specific type or sequence of questions or any particular form of questioning" (Fraenkel, Wallen, \& Hyun, 2012, p. 451). This kind of interview is to explore deeply the respondent's experiences, views, or feelings (Heigham \& Croker, 2009).

In interviewing the respondent, the writers used experience questions and feelings questions (Fraenkel, Wallen, \& Hyun, 2012). The experience questions focus on what the respondent has done in the past. The aim of this type of questions is to obtain the "descriptions of experience, behaviors, or activities that could have been observed but (for reasons such as the researcher not being present) were not" while the feeling questions focus on how the respondent feels about the things (p. 454). This type of questions is directed to the respondent's emotional responses toward her experience.

The interview was carried out by using WhatsApp chat application due to the Covid-19 pandemic which brought out the policy to do social and physical distancing. It was held on two days which lasted for $1 \frac{1 / 2}{2}$ to 2 hours per day. The interviews were conducted in bahasa Indonesia (local language) to make it more comprehensible. It also went in a casual manner to create comfort for the respondent. The writers started interview session by asking the respondent some questions about her general experiences and then asking some specific questions about several moments that could show her emotions.

\subsection{Data Analysis}

The interviews were firstly identified and made into mini stories. Then they were translated into English. The stories were coded with Hargreaves' emotional geography framework labeled with one of the five categories: physical, moral, sociocultural, professional and political geographies. The coding was done to classify the data. Heigham \& Croker, 2009) explain that coding means giving names or labeling the text that expresses a particular idea. They add "Coding breaks the data up into manageable pieces and gives these pieces names, or tags, which enables the researcher to manipulate them; for example, to group them together, regroup them, and classify them" (p. 51-52).

By accomplishing coding technique, it facilitated the researcher to easily classify each result of transcript conveyed from interview. The way presented the data, the writers referred to Liu's (2016) findings with the 5 labels of Hargreave's emotional geography.

\section{Findings and Discussion}

\subsection{Physical Geography: I thought that he was a firm and scary person}

When the first time Prili (pseudonym) came to school to start her teaching practice, she was welcomed in a very friendly way by the school's members. However, the only person she had to cooperate with during the teaching practice was her mentor teacher at the school. About how she got or met her mentor teacher, she said that it had been decided on the day she came. Right after the acceptance process of pre-service teachers from university, she was introduced to her mentor teacher who was a male.

Prili shared her feeling when, for the first time she met her mentor teacher who was counted as the new person to her that she should work or cooperate with. 
She shared a kind of her first impression towards him, in her words, 'I thought that he was a firm and scary person,' but after getting along and having talked, she found him not like how she thought at all. Here how she spilled out the encounter between her and her mentor teacher:

So the mentor teachers had been decided at the time of acceptance. In the speech, the school's public relation mentioned one by one who the mentor teachers would be there. Right after the acceptance process, I was called to have direct introduction. ... My feeling was for sure nervous, because when I looked at my mentor teacher by his appearance, I thought that he was firm and scary person, but after having chit-chat with him and he gave me a lot of guidance, he was just very kind and friendly.

Then I asked Prili about the continuance of her cooperation with her mentor teacher whether or not there was any difficulty she got or any different views between them during the guidance process, especially on planning the lesson. It just went really well for her:

\begin{abstract}
Alhamdulillah, there was no difference on the view of lesson plan matter. He gave me a freedom as long as it was suitable with the syllabus and the lesson was delivered well. ... The guidance process from him was kind of input or suggestions that very helpful, because the mentor teacher was professional, and knowledgeable about the school background or education. The guidance process was also kind of evaluation for me, when I was able to do improvement and adjustment.
\end{abstract}

Prili found no problem with her guidance process with her mentor teacher. Besides, she had meetings with him regularly and intensively. The meetings provided her the time and space to have physical interaction and proximity that made the cooperation between them go well. It was very helpful for her to do the improvement and adjustment towards what she had to do on her task based on the evaluation she got.

\title{
3.2. When I began staring at the students, I became normal again
}

Prili had tenseness every time she was about to enter the classroom to teach. There was a moment when she got confused about what she had prepared for teaching. She explained it as follow:

Of course I was tense every time I entered the class to start the lesson, but the tense disappeared at the moment later. As an example, I was feeling nervous the time I entered the class X Science 3, I was confused with what I have prepared, but when I began staring at the students, I became normal again - was not tense.

Prili actually could deal with it because the tense she felt slowly but surely disappeared as she began seeing the students, like she said, 'when I began staring at the students, I became normal again.' The first and the second stories provide evidences of pre-service teacher's connections with physical geography. To get improvement, Prili needs to create "close bonds and working situations" with the people in the school "to enable 'emotional understanding' of self and others" (Liu, 2016; Strohminger, Lewis, \& Meyer, 2011). In the community of teaching practice Prili had, her mentor teacher needed to build close bond with her. In the first story, Prili thought that her mentor teacher was a firm and scary person, which made her nervous when meeting him. However, with the time and space she had during the routine meetings of guidance process, her first thought disappeared by getting the reality that he was very kind and friendly. So, there was closeness in the cooperation 
and communication she experienced with her mentor teacher, and it was very helpful for her teaching practice continuity in the school. In line with the first story, the second story also shows the closeness created by the time and space before and after Prili sees the students every time she was about to teach. In her way of teaching, before seeing the students, she always became tense. But after she began staring at the students, her tenseness was gone and she became normal again.

\subsection{Moral Geography: I paid more attention to him by starting myself to come toward his desk and directly asked him}

Each student has different competence in comprehending the lesson, also has different personality. There was a moment when she taught a class, she found a male student who seemed does not to understand what was being taught by her in front of the class, but he did not brave to ask. So, she decided to come to his desk and ask him whether there was anything he could not understand and she offered herself to do her explanation again. Because when she came directly to his desk, he became brave to talk. She explained that experience below:

\footnotetext{
There was a male student whose competence of English was not too good. I paid more attention to him by starting myself to come toward his desk and directly asked him, "Is there anything that you couldn't understand? Miss will try to explain it again." Because when I directly came to his desk, he was not too shy to tell what he couldn't understand.
}

Prili had an eagerness to pay more attention towards certain students, whose competence is not too good in following the English subject - she taught. For Prili, there was such a motivation to deal with something related to her professional task, in this case was helping her student improve the way she knew of.

This story brings up pre-service teacher's moral geography when she found a student who seemed did not understand what she had been explaining but he did not brave to ask. So, she decided to use her morality by coming directly to his desk and ask him. She could do chancing "the strategies and tactics that have taken place in various emotional practices" (Zembylas, 2005) of distinct situations in teaching.

\subsection{Socio-cultural Geography: I used bilingualism}

Prili had to consider using full English when she taught students in the classroom, but she did not do it. Exactly, she used bilingualism:

Related to the use of English language itself in the teaching-learning process, it was not always. Usually, I used bilingualism. For example, "Please open the book page 36," then I repeated in bahasa Indonesia, so that the students understood.

Prili did it because of consideration of students' competence at that school and their competence to understand and speak English. Despite the school has been giving English lessons for a long time, it does not mean that the culture of using full English could be applied.

The story provides evidence of pre-service teachers' connection with sociocultural geography. There was a closeness built as Prili could understand the school's culture which did not use full English yet in the classroom of English subject. Prili had observed it so that she had 'understanding' to use bilingualism in giving the lesson instead of using full English. So, the context of using bilingualism in Indonesia actually cannot be avoided. 


\subsection{Professional Geography: I overcame that by substituting it with the other media}

Prili found a challenge about teaching media she had to use in classroom that made her to feel nervous. In college, exactly when she had practice in her microteaching class, what she always learned and used was full technology such as using projector, but the facility of the school she was placed at was not too adequate. That condition made her creativity work:

... because what I learned in college, everything was using full technology, but the school has not used that thing yet due to the facility that was not too adequate. I overcame that by substituting it with the other media, in the form of printed picture or puzzle.

Prili did not make it as an excuse to not use any media due to the limitation of projector; instead she made printed media to substitute it to keep the professionalism of her task or work.

\subsection{If there was any rationalization in my explanation so they could accept it}

Prili experienced something interesting. Her mentor teacher told her that there was one class that needed to be paid more attentions. Some unique but disobedient students in that class liked doing exercise while laying on the floor. Once she came teaching that class, she was a little shocked because she ultimately witnessed the students doing that. She said, they did it not because they have no chair to sit on but they were just kind of naughty. Here is what she explained:

\footnotetext{
There was something interesting happened. It was when my mentor teacher told me that there was one class which really needed to be watched out intensely, due to the number of students' uniqueness - exceedingly active, reaching to doing exercise on the floor while laid on their stomach - and it really appeared, when I taught that class, those students were indeed like that.
}

I asked Prili about what she did in that situation and whether she always told those students to sit on the chair. She said, she had ever told them not to do activity on the floor by laying their body on the stomach. She also tried to explain the effect of doing an activity while laying on the stomach:

\footnotetext{
... I ever asked them to do writing on the chair, I also explained how the bad effect of doing writing while laying on the stomach like that. If there was any rationalization in my explanation, so they could accept it. The days after that, they obeyed to sit on the chair.
}

She added the explanation about the effect of doing an activity while laying on the stomach because she wanted to give a clear saying, not only the instruction, which was sometimes not obeyed by the students. So, she did it to make those students accept and obey what she ordered from them. Eventually, they listened and obeyed.

\subsection{It was the very first time, so I got really nervous}

Prili experienced something which according to her, was embarrassing. That was when she went teaching the class for the very first time. She wanted to check the students' attendance. Before doing that, she told the students to say present if they were in. However, because the nervousness she felt, she accidentally said the word present in the wrong pronunciation which also had a different purpose from in:

... it was the very first time, so I got really nervous. There was usually the checking students' attendance activity in the beginning of the teaching-learning process, I told the students to 
say "present or I' $m$ here" if they were in, but I pronounced the present not in the purpose of 'in' instead of the present in the purpose of 'gift' or 'show or offer something.' Then one of my students said, "preznt, Miss, not pri'zent."

Prili got really shocked because of those short moments, because of herself who said pri'zent and because of one of the students who suddenly talked to correct her pronunciation. After that, she said sorry to the students for the incorrect pronunciation she did, and then said thanks to the student who helped her correcting what she said:

I did say sorry to them, there was also the student who by chance corrected my pronunciation, and then I did say thanks to that student and clarified that what I said was mistaken.

Actually, she did know what the correct one was. She made that mistake because it was really her first time teaching since her arrival at the school. However, she realized that she made a mistake, then said sorry instead of getting angry and denied her mistake to keep her professionalism. Realizing, saying sorry, and correcting her mistake, in fact, was the action which could support her professionalism.

\subsection{I hoped that I could be person who is assertive in the class}

After experiencing teaching with all real situations in school's teaching practice, Prili hoped to be more assertive in controlling the class situations in the future. It was because she found herself that she was not too assertive towards students when she was teaching them:

... I also hoped that I could be personal who is assertive in the class - managing the class situation if the uproar happens - because I was not too assertive back then when I had teaching practice, so that the students occasionally considered it as a common because the teacher was not angry nor reprimanded them.

Those stories provide evidences of pre-service teachers' wrestling with a professional geography. Prili met some moments where she had to deal with herself, students and the situations to create or keep professional work. Some of them show her negative emotions at first, but then changed to positive emotions. "When negative emotions happened, teachers need to engage the emotional work and management constantly" (Strohminger, Lewis \& Meyer, 2011; Liu, 2016). Prili did such things to keep her professionalism: substituting teaching media that the school could not provide; treating the unique (disobedient) students; changing the embarrassment, she got into the positive way; and having eagerness to improve her personality as a teacher to support herself in the future.

\subsection{Political Geography: I would feel bad}

There were two cases when Prili felt that she would feel bad if she did not do what she did. First, she was ever asked for help by her mentor teacher. She was asked to help him for the thing other than their teaching or lesson matter, but it was the thing to help him dispensing uniforms to the new students. At that time, she was in the middle of doing her task for her teaching needs:

... I was ever asked for help by my mentor teacher to dispense uniforms to the new students when I was making my student's activity sheet. I was able to do it, because my task was also not to be rushed and besides I would feel bad if I refused it. 
Prili of course, did not say "no" to that. She helped him. Besides, she was not too in a hurry to complete her task, prominently she would feel bad if she did not help him or refuse to do it. Second case was about the time she returned home from school. I asked her whether or not she returned home at the equal time as other teachers in the school, she told me that she and her teaching practice peers returned home late:

In MAN was still full, from Monday to Saturday, from 6.45 to 14.30 o'clock. I chose to return home late, because I would feel bad if I do it at the equal time as the other teachers. There was also an agreement with my friends that doing that stuff was to keep our reputation.

She did it because of who she was, as a comer and as pre-service teacher who had a teaching practice there. Besides feeling bad, it was also because of the agreement she and her teaching practice peers made that they should be longer at school and returned home later to keep their reputation to the school's community. They would not see her and her friends as the new people but wanted the same thing as others - local teachers. This indicates a success of discursive practices between pre-service teacher and situated school-teachers' professional sermon (Arvaja \& Sarja, 2020).

The last stories above give evidences of pre-service teacher's emotion to the political geography. The school as the community's social structure which the participant had the teaching practice at, for sure "has a shaping effect on teacher's emotions" (Liu, 2016). It is "premised on power structure that determines the order of interaction and practice" (Liu, 2016) and also enables and assimilates to academic problem and its overcoming situation as a place which strongly forms varieties of academic cooperation and awareness (Haraldstad \& Kristiansen, 2019). To the mentor teacher as one of the social structures with power of the community which in this case was school, Prili had feeling rules to always comply with what was told or asked and would not refuse anything because she knew that she would feel bad of it. To school, which was the professional community with all its power structures, she felt rules to behave well and anticipate herself from making mistakes or doing inappropriate things. Precisely in her case, she as a comer chose to stay longer at school rather than return home even though she was not asked to do it, but it was to complete the feeling rules that had been shown up. Drawing on the research findings, this research has a significant implication for teacher education, teacher educators, and cooperating teachers and pre-service teachers. In the initial teacher education context, being new, young, and having no teaching experience can pose a wide range of challenges for pre-service teachers like Prili. In order to engage in teaching practicum, she needs to enact emotional closeness with other community and builds professional learning to create 'emotional understanding' of self and other (Liu, 2016). For successful teaching practicum to get, therefore, both teacher educator and mentor teacher should address the crucial role of emotions in teaching practicum and mutually create emotional understanding during the professional learning. For the teacher education institution, it is essential to note the possibility of negative emotions on professional learning for pre-service teacher as they had no experience of teaching. 


\section{Conclusion}

The study presents ten mini stories of a female EFL pre-service teacher's emotional experience in a teaching practice at school for two months. Those ten stories indicated the five categories of Hargreaves' emotional geography framework that focuses on the physical, moral, socio-cultural, professional, and political aspects of schooling. The stories focus on her experience of collaboration with the mentor teacher, her sense to communicate with students, her experience of dealing with herself in adjusting the school's conditions, and her experience of the power structure in the school community. Teaching English and teaching practice is about transferring knowledge through language and involving a "social process". During the process, various and different emotions, both positive and negative arose. The participant mostly had positive emotions than negative ones. However, the negative emotions have existed, but the participant could deal herself with those. The limitation of the study reveals that this participant engaged in limited numbers while the study can not be generalized in the context of teaching practicum study. There, further investigation is to analyze the role of teaching practicum as a professional development site. The research had implications for the pre-service teacher to know her emotions and how she tried to deal with those various emotions to be engaged with all situations in teaching practice.

\section{References}

Arvaja, M., \& Sarja, A. (2020). Dialogic Tensions in Pre-Service Subject Teachers' Identity Negotiations. Scandinavian Journal of Educational Research, 65(2), 318-330. https:/ / doi.org/10.1080/00313831.2019.1705895

Bruner, J. S. (2003). Making stories: Law, literature, life. Harvard University Press.

Bullock, S. M. (2013). Learning to Teach and the False Apprenticeship: Emotion and Identity Development During the Field Experience Placement. Advances in Research on Teaching, pp. 119-140. Emerald Group Publishing Limited. https://doi.org/10.1108/s1479-3687(2013)0000018011

Connelly, F. M., \& Clandinin, D. J. (1999). Narrative Inquiry. Issues in Educational Research, pp. 132-140. Elsevier. https://doi.org/10.1016/b978-0080433493/50013-x

Darling-Hammond, L. (2009). Teacher Education and the American Future. Journal of Teacher Education, 61(1-2), 35-47. https:/ / doi.org/10.1177/0022487109348024

Dotger, B. H., Harris, S., Maher, M., \& Hansel, A. (2011). Exploring The Emotional Geographies of Parent-Teacher Candidate Interactions: An Emerging Signature Pedagogy. The Teacher Educator, 46(3), 208-230.

https://doi.org/10.1080/08878730.2011.581882

Fraenkel, J. R., Wallen, N. E., \& Hyun, H. H. (2012). How to design and evaluate research in education. McGraw-hill New York.

Haraldstad, Å., \& Kristiansen, A. (2019). Building bridges - between the pre-service teachers' school experiences and the teaching of an educational content. A narrative approach. Journal of Curriculum Studies, 52(5), 608-619. https:// doi.org/10.1080/00220272.2019.1658229

Hargreaves, A. (2001). Emotional Geographies of Teaching. Teachers College Record, 103(6), 1056-1080. https://doi.org/10.1111/0161-4681.00142 
Misdi, Desy Rachmawaty, Nurani Hartini, Kardi Nurhadi, Hendriwanto: Learner The Emotional Geography of A Female EFL Pre-service Teacher in Teaching Practicum: Voice from Initial Teacher Education

Hargreaves, A., \& Shirley, D. L. (2012). The global fourth way: The quest for educational excellence. Corwin Press.

Haviland-Jones, J. M., \& Kahlbaugh, P. (2004). Emotion and identity. In L. F. Barrett, M. Lewis, \& J. M. Haviland-Jones (Eds.), Handbook of emotions. NY: The Guilford Press.

Heigham, J., \& Croker, R. A. (Eds.). (2009). Qualitative Research in Applied Linguistics. London: Palgrave Macmillan UK. https:/ / doi.org/10.1057/9780230239517

Kaldi, S., \& Xafakos, E. (2017). Student teachers' school teaching practice: The relation amongst perceived self-competence, motivation and sources of support. Teaching and Teacher Education, 67, 246-258. https:/ / doi.org/10.1016/j.tate.2017.05.019

Kvale, S. (1996). InterViews: An Introduction to Qualitative Research Interviewing. Sage: Thousand Oaks. https:// doi.org/10.1016/S1098-2140(99)80208-2

Liu, Y. (2016). The emotional geographies of language teaching. Teacher Development, 20(4), 482-497. https:/ / doi.org/10.1080/13664530.2016.1161660

Rejeki, S., Kristina, D., \& Drajati, N. A. (2018). Emotional Geographies of an EFL Teacher in Asmat, Papua; Male Perspective. International Journal of Language Teaching and Education, 2(2), 113-121. https://doi.org/10.22437/ijolte.v2i2.5204

Riesky, R. (2013). How English Student Teachers Deal with Teaching Difficulties in Their Teaching Practicum. Indonesian Journal of Applied Linguistics, 2(2), 250. https://doi.org/10.17509/ijal.v2i2.169

Strohminger, N., Lewis, R. L., \& Meyer, D. E. (2011). Divergent effects of different positive emotions on moral judgment. Cognition, 119(2), 295-300. https://doi.org/10.1016/j.cognition.2010.12.012

Sulistiyo, U., Mukminin, A., Abdurrahman, K., \& Haryanto, E. (2017). Learning to Teach: A Case Study of Student Teachers' Practicum and Policy Recommendations. The Qualitative Report, 22(3), 712-731.

https:/ / doi.org/10.46743/2160-3715/2017.2671

Zembylas, M. (2003). Emotions and Teacher Identity: A poststructural perspective. Teachers and Teaching, 9(3), 213-238. https://doi.org/10.1080/13540600309378

Zembylas, M. (2005). Discursive practices, genealogies, and emotional rules: A poststructuralist view on emotion and identity in teaching. Teaching and Teacher Education, 21(8), 935-948. https://doi.org/10.1016/j.tate.2005.06.005

Zembylas, M., \& Schutz, P. A. (2009). Research on Teachers' Emotions in Education: Findings, Practical Implications and Future Agenda. In P. A. Schutz \& M. Zembylas (Eds.), Advances in Teacher Emotion Research (pp. 367-377). Boston, MA: Springer US. https://doi.org/10.1007/978-1-4419-0564-2_18

Zhu, G. (2017). Chinese student teachers' perspectives on becoming a teacher in the practicum: emotional and ethical dimensions of identity shaping. Journal of Education for Teaching, 43(4), 491495.

https://doi.org/10.1080/02607476.2017.1341162 